九州大学学術情報リポジトリ

Kyushu University Institutional Repository

\title{
A New Laminariaceous Alga Found In Izu
}

Segawa, Sokichi

Fisheries Laboratry, Department of Agriculture, Kyusyu University

https://doi.org/10.5109/22609

出版情報：九州大学大学院農学研究院紀要. 9 (1)，pp.59-63，1948-03. Kyushu University バージョン：

権利関係 : 
Journal of the Faculty of Agriculture, Kyūshü Unversity, Vol. 9, No, 1

March 15, 1948

\title{
A NEW LAMINARIACEOUS ALGA FOUND IN IZU*
}

\author{
SoKichi SEgawa
}

In early part of 1938 the author of this paper collected a new Laminariaceous alga dredged from a depth of more than 20 meters at Arashidomari near Susaki, Izu Province. During the same year in late April, at Toji, a western village of the same locality, the author obtained more specimens of the same species found in the 'Ebi-ami', a bottom gill-net, probably from a depth of more than 20 meters, as in the former case. Despite the author's perseverance to collect more specimens, to complete the study of this new species, subsequent efforts were fruitless. Thus it may be concluded that the species is rare in this region. However, it is noteworthy to find a new Laminariaceous alga thriving in such a warm sea as in Izu Province.

No less than 15 specimens are at hand, and among these almost the entire lot are fragments, only 4 (No. 1-4) were satisfactory for the study described below:

Specimen, No. 1-The specimen is nearly complete, the holdfast consists of three hapteres, one of which is undivided and the rest branched few times dichotomously. The shape is very short, ca $2 \mathrm{~mm}$ long, compressed, ca $3 \mathrm{~mm}$ wide, slightly concave in the ventral side. The blade is membranaceous, ovate, ca $7 \mathrm{~cm}$ long, ca $6 \mathrm{~cm}$ wide, almost flat, but more or less concave near, and distinctly cordate at the base, with a subintegral and less crispate margin. The blade does not stand erect but extends horizontally, bending at the base (Fig. 1-A).

* Contribution from the Fisheries Laboratory, Facuity of Agriculture, Kyushu University, Fukuoka, \& the Mitsui Institute of Marine Biology, Susaki near Shimoda, Izu. 
Specimen, No. 2-The stcond specimen is also nearly complete. Comparing with the precting specimen, the blade is about equal in length but the brradth is about twice as wide. The margin of both sides is integral, but at the upper side the erosion is apparent. At the central part of the blade a slit occurs (Fig. 1-B).

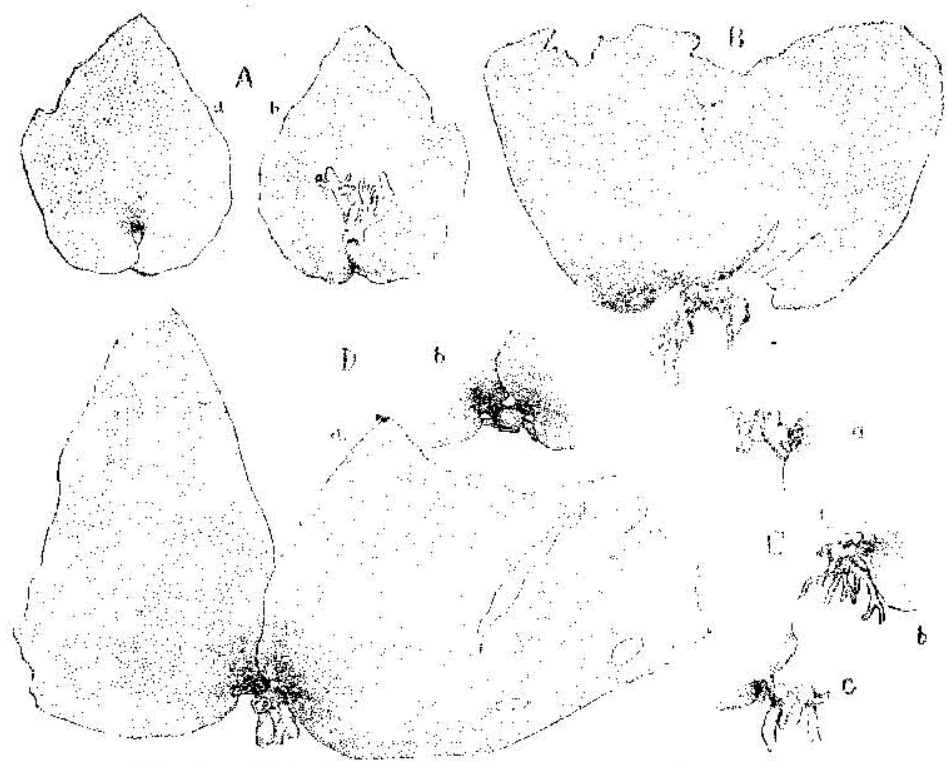

Fig. 1. Hedophyllum (?) kuroshioense Segawa $\times 1 / 3$
A.-Specimen No. 1 (a.-seen from above; b.-seen from below)
B. - Specimen No. 2
C. -Specimen No. 3 (a.-seen from above; b.- seen from the side; c- - seen from other side)
D. - Specimen No, 4 (a.-seen from the side; b.-a part seen from above)

Specimen, No. 3-The specimen with one blade seems to be incomplete as to the bladc, but is complete in the holdfast. A leaf scar which is distinctly visible indicates a possibility that it possessed two blades at one time. As in specimen No. 1 the blade is slightly concave near and cordate at the base, with a subintegral and less crispate margin. The blade extends almost horizontaliy bending at the base. The stipe is short, compressed, concave in the ventral side. A pair of blades are diametrically opposite each other, expanding almost horizontally. There are 
two globular protuberances, being ca $4 \mathrm{~mm}$ in diameter, between two stipes of these opposed blades. From both saides of such protuberances six hapteres issue downwards. They are still short and undivided. Just below the contacting portion of these protuberances, such a holdfast as shown in specimen No. 1 is seen, consisting of four hapteres in all Fig. $1-\mathrm{C}$ ).

Specimen, No. 4-This is a mutilated specimen having two blades. Blades resemble, in appearance, those of the preceding specimen. They differ only in size, being ca $12 \mathrm{~cm}$ wide. They have a short, compressed stipc issuing contiguously with each other from one side of a same globular protuberance. In the other side of the globular protuberance, a broken scar is seen (Fig. 1-D).

In the critical examinations of the 4 specimens it seems probable that they represent the successive stages of development in this species of alga. The assumption is not unreasonable considering also from the cases of some other Laminariaceous algae. The successive stages of development were achieved as follows: the form of specimen No. 2 is believed to be an advanced stage from No. 1. The simplex blade becomes broader, a slit appearing at the center, and the erosion is seen in the upper margin; from this stage the form of specimen No, 3 is derived. The two armed plant bearing secondary blades seems to be formed as the result of the activity of the transition region of the blade. At this stage two bifurcate arms are arranged almost diametrically opposite in a row. Each arm characteristically develops into two differentiated parts, the stipe of the secondary blade and its successive globular protuberance. In this specimen six secondary hapteres issue downward from the armed portion. They are young, undivided, and still not long enough so that the clump of the primary hapteres is uncovered by them; specimen No. 4 shows a part of the further developed stage of the third. The secondary blade seems to produce two tertiary ones by the same course as in the formation of secondary blade. In the present specimen, however, the differentiation of the newly produced arm mentioned above is not shown, and two blades are arranged in bifurcation at almost right angles to each other.

Basing upon the four specimens mentioned here in, the diag. 
nosis can be given as follows, though some other characters may be added in the future collection.

\section{Hedophyllum (?) kuroshioense spec. nov.}

Planta primo cum stipite sine ramis; lamina ad basin curvata, horizontaliter ixpansa; dein bifurcata; stipite secundo ex parte globosa et parte compressa, brevissima composito, in lamina secunda terminanti. Radix primo fasciculata, e rhizinis dichotome ramosis composita, dein rizinis secundis e stipite secundo evolutis. Stipes primus brevissimus, ca $2 \mathrm{~mm}$ longus, compressus; ca $3 \mathrm{~mm}$ latus, leviter canaliculatus. Lamina prima simplex, ovata, plana, sed ad basin leviler concava, ca $7 \mathrm{~cm}$ longa, ca $6 \mathrm{~cm}$ lata, margine integra et non crispata. Laminae secundae et tertiae simplices, ovatae (?), majores, basi paulo cordatae, prope horizontaliter expansae. Sporangia ignota.

Japanese name. Kuroshio-me (n. n.)

Type locality. Tōji, Izu Province.

Type specimen in the Herbarium of the Mitsui Institute of Marine Biology.

The reason to place provisionally the present new alga under the genus Hedophyllum is that it has some resemblance to $H$. subsessile in the aduanced stage bearing the bifurcate arms. The present plant, however, differs distinctly from the latter by having the bifurcate arms characteristically metamorphosed as shown above. Namely, $H$. subsessile has the arms which are decumbent, somewhat long, much concave. In $H$. kuroshioense such portion is very compact, metamorphosed into two parts, a short, compressed stipe and a globular protuberance. Moreover, the secondary blades of $H$. subsessile split into many segments and are much concave near the base, while in $H$. kuroshioense they are undivided and slightly concave. Though there are such distinct differences existing between these species, it seems that the general appearance of such advanced form bearing secondary arms is the same between these species.

However it must be mentioned that there are some other members of Laminariaceae having bifurcate arms in their advanced stage. In the classification of them the developmental observa- 
tions of bifurcation are very necessary. Because of an inadequate supply of specimens, the present alga has been not studied in such respect in detail. This is the reason to be marked with a query on the genus name.

Here the author wishes to express his sincere thanks to Prof. Dr. Y. Yamada, under whose direction the writer's work has been carried on. Thanks are also due to Prof. Dr. K. Uchida and Prof. Dr. I. Amemiya for their kind help during the course of this study. 